FisiPublik: Jurnal Ilmu Sosial dan Politik

https://journal.uwgm.ac.id/index.php/fisipublik

P-ISSN: 2528-2689; E-ISSN: 2540-9751

Vol 05 No 01 Mei 2020

\title{
Analisis Partisipasi Politik Ulama Dalam Pilkada Serentak di Kabupaten Polewali Mandar
}

\section{Amin', Farida Utami², Fitriani Sari Handayani Razak ${ }^{3}$}

${ }^{1}$ Program Studi Pendidikan Agama Islam, Fakultas Agama Islam, Universitas Muhammadiyah Makassar

${ }^{23}$ Program Studi Ilmu Pemerintahan, Fakultas Ilmu Sosial dan Ilmu Politik, Universitas Muhammadiyah Makassar

Email: amin@unismuh.ac.id, Faridautami@gmail.com, Fitrianisari@unismuh.ac.id

\begin{abstract}
Abstrak
Artikel ini membahas tentang partisipasi politik ulama dalam Pilkada Serentak di Kabupaten Polewali Mandar. Dalam tradisi perpolitikan di Polewali Mandar, tokoh agama utamanya Ulama menjadi perhatian sentral oleh masyarakat di tempat tersebut. Hal ini disebabkan karena Ulama menjadi sosok yang didengar dan diikuti ucapan dan pilihannya, sehingga setiap calon bupati dan wakil bupati yang akan ikut dalam pilkada pasti akan terlebih dahulu melakukan kunjungan politik kepada Ulama-ulama kharismatik di Polewali Mandar. Jenis penelitian yang digunakan dalam penelitian ini adalah penelitian kualitatif dengan pendekatan deskriptif. Hal menarik yang didapatkan pada kondisi Pilkada Serentak di Polewali Mandar adalah Partisipasi Politik Pemilih Ulama' dalam Pemilukada 2018 di Kecamatan Wonomulyo Kabupaten Polewali Mandar. Partisipasi aktif, ulama terlibat aktif dalam menentukan proses pemilihan bupati, karena pemilihan bupati adalah masalah penting yang merupakan kepentingan masyarakat umum, dan ulama di anggap sebagai contoh pemilih pemimpin yang benar, serta ulama dinilai masyarakat sebagai mediator jika terjadi konflik kepentingan antar pendukung
\end{abstract}

Kata Kunci : Partisipasi politik; Pilkada Serentak; Politik Ulama 
FisiPublik: Jurnal Ilmu Sosial dan Politik

https://journal.uwgm.ac.id/index.php/fisipublik

P-ISSN: 2528-2689; E-ISSN: 2540-9751

Vol 05 No 01 Mei 2020

The Political Participation Of Ulama In The Simultaneous Local Election In Polewali

Mandar Regency

\begin{abstract}
This article discusses the political participation of ulama in the Simultaneous Local Election in Polewali Mandar Regency. In the political tradition in Polewali Mandar, the main religious figure of Ulama is the central concern of the people in that place. This is because the Ulama become a figure who is heard and followed by their words and choices, so that every candidate for regent and deputy regent who will participate in the elections will first make a political visit to the charismatic Ulama in Polewali Mandar. This type of research used in this study is a qualitative research with a descriptive approach. An interesting thing that was obtained in the condition of Simultaneous Local Election in Polewali Mandar was the Political Participation of Ulama Voters' in the regional head election in Wonomulyo Subdistrict, Polewali Mandar Regency. Active participation, scholars are actively involved in determining the district head election process, because the election of the district head is an important issue that is in the interests of the general public, and scholars are considered an example of a true leader voter, and scholars are considered by the community as mediators in the event of a conflict of interest between supporters
\end{abstract}

Keywords:Political Participation; Local Election; Ulama Politics 


\section{FisiPublik: Jurnal Ilmu Sosial dan Politik}

https://journal.uwgm.ac.id/index.php/fisipublik

P-ISSN: 2528-2689; E-ISSN: 2540-9751

Vol 05 No 01 Mei 2020

\section{Latar Belakang}

Menurut sistem politik yang demokratis, pemilu merupakan sarana bagi suatu partai politik untuk memperoleh dukungan dan kepercayaan rakyat. Manakala dalam penyalenggaraan pemilu suatu partai politik memperoleh suara terbanyak maka parpol tersebut akan mendapat mandat dari rakyat untuk membentuk pemerintahan. Oleh kerena itu pemilihan umum dapat diartikan sebagai sarana yang dapat memungkinkan terjadinya perubahan pemerintahan secara damai. Esensi demokrasi adalah partisipasi politik. Penentuan pejabat politik merupakan bagian dari partisipasi politik. Pemilihan pejabat politik secara langsung lebih demokratis dibandingkan melalui mekanisme perwakilan. Dalam konteks pemilu maka pemilihan secara langsung kepala daerah pada gilirannya akan meningkatkan kualitas keterwakilan karena masyarakat menentukan pemimpinnya sendiri. Keterlibatan masyarakat secara langsung dalam proses pemilihan kepala daerah ini pada gilirannya nanti memperkuat legitimasi kepala daerah.

Bangunan demokrasi tidak akan kokoh manakala kualitas partisipasi masyarakat diabaikan. Karena itu, proses demokratisasi yang sejatinya menegakkan kedaulatan rakyat menjadi semu dan hanya menjadi ajang rekayasa bagi mesin-mesin politik tertentu. Format demokrasi pada aras lokal (pilkada) meniscayakan adanya kadar dan derajat kualitas partisipasi masyarakat yang baik

. Dalam Islam pun tentunya tak lepas dari namanya politik. Tak bisa dipungkiri bagi kaum Muslimin dewasa ini, bahwa Islam merupakan jalan hidup yang meliputi aspek-aspek fisik, politik dan spiritual. (Ezzatti,1990). Hal ini dapat juga disebut dengan istilah Islam politik, yaitu pencerminan dari ajaran Islam mengenai politik (hubungan manusia dengan kekuasaan yang diilhami oleh petunjuk Allah) yang telah bercampur dengan berbagai kepentingan manusia. (Kanim,1999).

Kajian mengenai Islam politik lebih merupakan usaha mempelajari perilaku politik seorang atau umat Islam yang didorong oleh kesadaran keagamaan (Islam). Pengaruh ulama tidak hanya pada masyarakat awam tetapi juga merambah pada para pejabat atau tokoh partai politik. Dan juga melibatkan dirinya dalam pemilihan langsung, Dalam kenyataan empirik bahwa ulama banyak diperebutkan oleh orang yang menduduki jabatan politisi tertentu. (Abdurrahman,2009).

Hingar bingar dan tarik menarik ulama dalam pemilu, pemilihan gubenur, Bupati/walikota menandakan bahwa tarikan kepentingan politik ulama masih besar. Ulama-ulama kita terdahulu mengagungkan nilai politik dan keutamaannya sehingga Imam Ghazali mengatakan, 


\section{FisiPublik: Jurnal Ilmu Sosial dan Politik}

https://journal.uwgm.ac.id/index.php/fisipublik

P-ISSN: 2528-2689; E-ISSN: 2540-9751

Vol 05 No 01 Mei 2020

"sesungguhnya dunia itu merupakan ladang untuk akhirat, dan tidaklah sempurna agama tanpa Dunia.

Kabupaten Polewali Mandar yang merupakan sebuah kota yang penduduknya mayoritas beragama Islam. Kehidupan religius dan menghargai serta mengikuti fatwa seorang ulama' masih sangat kental. Dimana setiap tindakan yang dilakukan seorang ulama di benarkan adanya, salah satunya ialah cara memilih ataupun menentukan hak pilihnya untuk seorang pemimpin atau calon kepala daerah. Karena ulama' masih dianggap orang yang mampu mempertahankan keagamaan secara baik, sehingga perilaku mereka merupakan panutan bagi masyarakat. Disinilah pentingnya peran ulama' untuk meningkatkan partisipasi politik dalam pemilukada di Kabupaten Polewali Mandar. Melihat kentalnya kehidupan agama dikalangan masyarakat di Kabupaten Polewali Mandar baik di daerah perkotaan, pedalaman, maupun pesisir sudah dapat dipastikan tidak terlepas dari peran penting seorang elit politik dan ulama. Dalam falsafah Jawa khususnya di Kecamatan Wonomulyo Kabupaten Polewali Mandar ning endiwae kyai mlaku wong cilik tinggal nunut, yang artinya kemanapun seorang ulama melangkah maka masyarakat akan mengikutinya. Meskipun dengan keyakinan demikian seringkali dimanfaatkan untuk mendukung salah satu paslon dalam pemilu yaitu dengan cara memilih langsung, hal ini bukanlah masalah asal tetap dalam koridor norma-norma agama maupun hukum positif yang berlaku di Indonesia.

Partisipasi politik dapat didefinisikan sebagai upaya warga masyarakat, baik secara individual maupun kelompok, untuk ikut serta memengaruhi pembentukan kebijakan publik dalam sebuah negara, partisipasi politik diartikan sebagai penentuan sikap dan keterlibatan setiap individu dalam situasi dan kondisi organisasinya, sehingga pada akhirnya mendorong individu tersebut untuk berperan serta dalam pencapaian tujuan organisasi serta ambil bagian dalam setiap pertanggung jawaban bersama (Rahman.2002).

Penelitian yang membahas tentang Partisipasi politik ulama yang berjudul Partisipasi politik tokoh agama dalam proses pengambilan kebijakan publik pemerintah kota tanggerang (Studi Kasus Perda no.7 dan 8 tahun 2005) menjelaskan tentang, Tingkat partisispasi politik tokoh agama Budha dan Hindu termasuk dalam katagori rendah karena masing-masing hanya melakukan tiga bentuk partisipasi. Begitupulah dengan tingkat partisipasi tokoh agama khonghucu dan katolik termasuk dalam katagori rendah karena masing-masing hanya melakukan dua bentuk partisipasi. Dan Protestan hanya melakukan satu bentuk partisipasi termasuk dalam katagori teramat rendah. 


\section{FisiPublik: Jurnal Ilmu Sosial dan Politik}

https://journal.uwgm.ac.id/index.php/fisipublik

P-ISSN: 2528-2689; E-ISSN: 2540-9751

Vol 05 No 01 Mei 2020

Sedangkan tingkat partisipasi tokoh agama islam termasuk dalam kategori sedang karena tokoh aagama islam melakukan empat bentuk partisipasi.

Penelitian yang lain juga pernah di bahas tentang Partisipasi Ulama Dalam Partai Politik menjelaskan tentang Indonesia memulai babak baru dalam lintasan sejarahnya ketika rezim orde baru berhasil di runtuhkan pada 1998 dan berganti menjadi masa yang di sebut sebagai orde reformasi dan memunculkan kembali kekuatan- kekuatan yang pada amsa orde baru di belenggu, yaitu kekuatan politik islam yang kemudian membentuk berbagai partai politik islam untuk menyuarakan aspirasinya dan ikut serta dalam proses demokrasi melalui pemilihan umum. Dalam kurun waktu 1998-2009 tercatat telah di laksankan tiga kali proses pemilihan umum di tingkat nasional yaitu 1999, 2004 dan 2009. Serta satukali pemilihan kepala daerah cianjur yaitu pada 2006. Partisipasi ulama dalam partai politik sebagai pembimbing spritual di kalangan kafir partai politik, serta menjadi pengarah masyrakat dan penghormatan atas kualitas keilmuan yang mereka miliki (Deden. 2011).

Penelitian yang lain yang berjudul Partisipasi Ulama Dayah Dalam Partai Politik Lokal Aceh (Studi kasus Pada DPCPNA, PA, dan PDA Kabupaten Aceh Selatan) menjelaskan tentang Partisipasi ulama dayah dalam partai politik sangatlah penting, ini bisa dilihat dari banyaknya ulama yang terlibat dalam pengurus partai politik lokal, selain penyeimbang dalam kepengurusan partai, ulama juga berperan sebagi orang yang bisa menyelesaikan masalah dalam tubuh partai jika ada halhal yang tidak bisa di selesaikan secara personal dalam partai, maka ulama berperan dalam menyelesaikan masalah tersebut (Arif. 2018). Tujuan dari artikel ini adalah untuk mengetahui partisipasi politik pemilih ulama, dalam pelaksanaan pemilukada di Kecamatan Wonomulyo Kabupaten Polewali Mandar.

\section{Metodologi}

Penelitian ini dilaksanakan di Kecamatan. Wonomulyo Kabupaten Polewali Mandar dengan objek penelitian adalah Ulama yang berpartisipasi dalam pemilukada di Kabupaten Polewali Mandar 2018, dimana tokoh agama dan Ulama merupakan sasaran dari berbagai calon bupati yang mengikuti kontestasi politik pada Kabupaten Polewali Mandar hal ini terjadi di karenakan pengetahuan terhadap dinamika politik yang ada pada partisipasi Ulama masih sangatlah kurang. Waktu penelitian adalah dua bulan mulai dari bulan Februari/Maret 2019. 


\section{FisiPublik: Jurnal Ilmu Sosial dan Politik}

https://journal.uwgm.ac.id/index.php/fisipublik

P-ISSN: 2528-2689; E-ISSN: 2540-9751

Vol 05 No 01 Mei 2020

Jenis penelitian yang digunakan dalam penelitian ini adalah penelitian kualitatif dengan pendekatan deskriptif. Penelitian kualitatif dengan pendekatan diskriptif dimaksudkan untuk memberikan gambaran mengenai Partisipasi Politik pemilih ulama dalam pemilukada 2018 di Kecamatan Wonomulyo Kabupaten Polewali Mandar.

Informan merupakan individu atau orang-orang yang mampu memberikan informasi mengenai permasalahan yang ingin diteliti dalam penelitian ini adalah di tentukan secara perposive sampling yang bertujuan peneliti memilih informan atau responden secara sengaja, yaitu mereka yang di anggap berkompeten atau di anggap tahu pasti tentang. Partisipasi politik pemilih ulama dalam pemilukada tahun 2018 di Kecamatan Wonomulyo Kabupaten Polewali Mandar.

Teknik analisis data yang digunakan dalam penelitian ini adalah bersifat kualitatif yaitu analisis deskriptif kualitatif itu sendiri yaitu analisis yang tidak berdasarkan perhitungan angka melainkan dalam bentuk pertanyaan-pertanyaan yang digunakan secara deskriptif. Analisis data dalam penelitian ini dengan menggunakan analisis data kualitatif, setelah di kelompokan data tersebut di jabarkan dalam bentuk wacana sehingga lebih di mengerti, setelah itu dari wacana tersebut maka peneliti akan menarik kesimpulan dari data tersebut sehingga dapat menjawab pokok masalah penelitian.

\section{Pembahasan}

Kabupaten Polewali Mandar terletak di Sulawesi Barat dengan luas wilayah sebesar 2.022,30 km2. Secara administratif, Kabupaten Polewali Mandar terbagi ke dalam 16 kecamatan. Di Kabupaten Polewali Mandar mayoritas penduduknya beragama islam. Kehidupan religius dan menghargai serta mengikuti fatwa seorang ulama masih sangat kental, karena bagi mereka seorang ulama masih di anggap orang yang mampu mempertahankan ke agamaan secara baik sehingga peran elit agama atau kiyai atau ulama untuk terlibat dalam proses pemilu baik secara structural tergabung dalam kelembagaan partai politik atau dalam tim pememenagan atau bahkan hanya sebagai pemilih, merupakan warna tersendiri bagi kehidupan Demokrasi di daerah Polewali Mandar.

Hal ini sesuai dengan sebuah Falsafah Jawa Neng endi wae kiyai mlaku wong cilik tinggal nunut yang artinya kemanapun seorang ulama melangkah maka masyrakat akan mengikutinya, terlebih di kecamatan Wonomulyo yang merupakan wilayah masyrakat jawa dan para ulama. Pemerintahan adalah suatu sistem yang mengatur segala kegiatan penduduk di daerah/negara 


\section{FisiPublik: Jurnal Ilmu Sosial dan Politik}

https://journal.uwgm.ac.id/index.php/fisipublik

P-ISSN: 2528-2689; E-ISSN: 2540-9751

Vol 05 No 01 Mei 2020

tertentu meliputi segala aspek kehidupan berdasarkan norma-norma atau aturan-aturan tertentu. Peran pemerintahan dalam membangun sangat menetukan majunya suatu wilayah. Untuk itu diperlukan perangkat-perangkat pemerintahan yang mampu menampung aspirasi dan mengayomi masyarakat. Wilayah administrasi Kecamatan Wonomulyo dengan ibu kota Kelurahan Sidodadi terdiri dari tiga belas desa dan satu kelurahan yaitu desa Tumpiling, Desa Nepo, Desa Kebunsari, Desa Arjosari, Desa Bumiayu, Desa Bumimilyo, Desa Sidorejo, Desa Campurjo, Desa Sumberjo, Desa Sugihwaras, Desa Banua Baru, Desa Bakka-bakka, dan Desa Galesong serta Kelurahan Sidodadi. Kecamatan Wonomulyo di Kepalai oleh seorang camat, yang di dalam melaksanakan tugasnya dibantu oleh seorang sekretaris camat, kasi pemerintahan, kasi ekbang, kasi trantib, dan kasi kessos serta kasi Pemberdayaan Masyarakat Desa (PMD). Setiap desa/kelurahan dikepalai oleh masing-masing kepala desa dan lurah.

\section{Partisipasi aktif}

Peranan dan fungsi dari tokoh agama sangat penting dalam mengendalikan ketegangan sosial yang terjadi di masyarakat dalam iklim yang semakin demokrasi ini. Tokoh agama berperan sangat penting dalam menciptakan atau membentuk opini publik atau pendapat umum yang sehat. Oleh karena itu, isu-isu yang menyesatkan dan kabar bohong yang tersebar bisa ditangkal masyarakat bila selalu berada di bawah bimbingan tokoh agama. Tokoh agama atau pemimpin adalah orang yang menjadi pemimpin dalam suatu agama, seperti para kiai, ulama, pendeta, pastor dan lain-lain. Keberadaan tokoh agama di masyarakat sering kali lebih di dengar perkataan-perkataannya dari pada pemimpin-pemimpin yang lain, serta tindakanya yang sering di jadikan panutan tersendiri di kalangan masyarakat.

Oleh karena itu, isu-isu yang menyesatkan dan kabar bohong yang tersebar bisa ditangkal masyarakat bila selalu berada di bawah bimbingan tokoh agama. Tokoh agama atau pemimpin adalah orang yang menjadi pemimpin dalam suatu agama, seperti para kiai, ulama, pendeta, pastor dan lain-lain. Keberadaan tokoh agama di masyarakat sering kali lebih di dengar perkataan-perkataannya dari pada pemimpin-pemimpin yang lain, serta tindakanya yang sering di jadikan panutan tersendiri di kalangan masyarakat.

Dari pernyataan di atas dapat dikatan bahwa keterlibatan aktif ulama dalam pilkada di Polewali Mandar berpandangan sesuatu yang sangat penting dilakukan karena ini masalah masa 


\section{FisiPublik: Jurnal Ilmu Sosial dan Politik}

https://journal.uwgm.ac.id/index.php/fisipublik

P-ISSN: 2528-2689; E-ISSN: 2540-9751

Vol 05 No 01 Mei 2020

depan masyarakat umum, kemudian ulama juga sangat dinanti dan diharapkan keterlibatannya selain bisa dijadikan contoh juga sangat memengaruhi arah dukungan ke salah satu paslon terlihat dari penghormatan masyarakat terhadap ulama dan juga ulama dianggap mampu sebagai mediator yang baik jika terjadi konflik atau gesekan-gesekan antara para pendukung calon kepala daerah. Dengan kata lain, jika para tokoh atau pemuka agama bersinergi untuk saling memberi pemahaman kepada para jamaah mereka, maka setidaknya akan dapat meminimalisasi masalahmasalah sosial politik di negara ini khusunya di Polewali Mandar.

Hal ini sama dengan partisipasi ulama dalam partai politik lokal di Aceh Selatan bahwa ulama juga berperan sebagai orang yang bisa mengendalikan ketegangan sosial dan menyelesaikan masalah dalam tubuh partai jika ada hal-hal yang tidak bisa di selesaikan secara personal dalam partai, maka ulama berperan dalam menyelesaikan masalah tersebut, serta ulama selalu di dengar ucapan dan fatwa-fatwanya serta tindaknya menjadi panutan bagi masyarakat setempat.

\section{Partisipasi pasif}

Partisipasi fasif atau minimnya partisipasi biasa disebabkan oleh beberapa hal, di antaranya pasangan calon yang tidak memenuhi ekspektasi masyarakat. Sementara masyarakat menginginkan perubahan dan perbaikan yang cepat untuk daerahnya, dan hal seperti ini sering terjadi pada setiap pemilukada bahkan pemilihan umum di setiap daerah. Serta fenomena masyarakat yang acuh tak acuh dalam proses demokrasi di negara ini.

Dari pernyataan hasil wawancara di atas minimnya partisipasi ini bisa disebabkan oleh pasangan calon yang tidak memenuhi ekspektasi masyarakat. Masyarakat menginginkan perubahan dan perbaikan yang cepat. "Karena pasangan calon tak sesuai keinginan, banyak pemilih yang tidak datang ke TPS."Dalam konteks Indonesia yang mempunyai berbagai ragam suku bangsa dan beberapa agama (Islam, Katolik, Protestan, Hindu, Budha, Kong Hucu), maka akan sangat mudah sekali dan rentan akan chaos kepentingan dan hal ini juga bisa jadi pemicu rendahnya partsipasi ulama atau fasif karena sebagai ulama tidak seharusnya ikut menebar kebencian antar sesama. Apalagi jika kaitannya dengan politik. Untuk menangkal agar tidak terjadi kericuhan sana-sini, maka diperlukan adanya sinkretisme. Sinkretisme di sini yaitu kebersamaan kelompok-kelompok (agama-agama) yang berbeda-beda untuk menghadapi musuh 


\section{FisiPublik: Jurnal Ilmu Sosial dan Politik}

https://journal.uwgm.ac.id/index.php/fisipublik

P-ISSN: 2528-2689; E-ISSN: 2540-9751

Vol 05 No 01 Mei 2020

bersama yang akan menghancurkan dan memporak-porandakan Negara Kesatuan Republik Indonesia (NKRI) ini.

\section{Golongan putih (golput) atau kelompok apatis.}

Sebagian besar mereka yang golongan putih (golput) menganggap bahwa para penyelenggara negara dan partai-partai yang ada tidak menyuarakan dan pro-kebaikan berpolitik. Jadi, lebih baik tidak memilih siapapun daripada memilih partai yang ada atau calon kepala daerah. Mereka beranggapan bahwa partai-partai yang ada akan berperilaku buruk juga apabila memenangkan pemilu. Golongan putih (golput) bukan merupakan organisasi yang diatur oleh instrumen peraturan. Hal tersebut juga tidak dikoordinasi melalui sistem manajemen. Golongan putih (golput) hanya sebagai penyebutan kepada akumulasi pribadi-pribadi yang tidak ikut pemilu atau ikut pemilu tetapi dengan cara merusak surat suara. Dari beberapa hasil wawan cara di atas dapat di simpulkan bahwa daerah yang menganut asas demokrasi golongan putih (golput) tidak dilarang. Hal ini mengacu pada prinsip bahwa tidak memilih pun merupakan suatu pilihan. Seseorang tidak dapat dipaksa untuk memilih terhadap pilihan-pilihan yang menurut penilaiannya tidak ada yang sesuai dengan prinsip politiknya.

\section{Kesimpulan}

Partisipasi Politik Pemilih Ulama' dalam Pemilukada 2018 Di Kecamatan Wonomulyo Kabupaten Polewali Mandar. Partisipasi aktif, ulama terlibat aktif dalam menentukan proses pemilihan bupati, karena pemilihan bupati adalah masalah penting yang merupakan kepentingan masyarakat umum, dan ulama di anggap sebagai contoh pemilih pemimpin yang benar, serta ulama dinilai masyarakat sebagai mediator jika terjadi konflik kepentingan antar pendukung. Partisipasi Fasif, faktor rendahnya partisipasi sebagaian ulama yaitu karena terbatasnya pilihan calon yang diajukan partai poltik, tidak terwujudnya janji kampanye dengan realitas politik dan kurangnya sosialisasi yang dilakukan oleh penyelenggara pemilukada. Golongan Putih (golput) Atau Kelompok Apatis, Jarang terlihat ada ulama golongan putih (golput) karena ulama terang-terangan mendukung salah satu calon kepala daerah untuk maju dan berharap untuk dipilih calonnya. Jika ada ulama atau masyarakat golongan putih (golput) itu karena tidak tercantum di daftar pemilih tetap, perantau yang 


\section{FisiPublik: Jurnal Ilmu Sosial dan Politik}

https://journal.uwgm.ac.id/index.php/fisipublik

P-ISSN: 2528-2689; E-ISSN: 2540-9751

Vol 05 No 01 Mei 2020

tekendala administrasi, tekanan dari pihak lain untuk tidak memilih, kurang kesadaran politiknya, dan kelalaian.

\section{Daftar Pustaka}

Abdurrahman, (2009). Fenomena Kiai dalam Dinamika Politik.Jurnal Karasa, Vol. xv No. 1

Arif, Budiman, (2018). Partisipasi Ulama Dayah Dalam Partai Politik Lokal Aceh (Study Kasus Pada DPC PNA, PA Dan PDA Kabupaten Aceh Selatan). Aceh, Vol 5, No 2.

Deden, Gumilang, (2011). Partisipasi Ulama Dalam Partai Politik Di Cianjur (1999-2009). Bandung, Vol 3, No 2.

Ezzatti, A. (1990).Gerakan Islam Sebuah Analisis.Jakarta: Pustaka Hidayah.

Kanim Rusli, M. (1999). Negara dan Peminggiran Isalam Politik, Yogyakarta: PT Tiara .

Rahman, Arifin. (2001). Sistem Politik Indonesia. Surabaya: SIC, 2002 Jakarta: Rineka Cipta. 